\title{
The crisis in the Finnish Data Processing Museum Association - a practical use of museality
}

EMMI TITTONEN*

\begin{abstract}
The history of computers is short, but very important in regard to today's society. There are several computer museums in the world but only one computer museum association in Finland. The Finnish museum association's collection of computers was in jeopardy of being totally broken up in 2007. However, this internationally important collection was saved via a move to new storage facilities and the rebuilding of the collection. This article describes the story of a museum association that has collected the most important computers in Finnish IT history and the crisis it went through in order to continue its work.
\end{abstract}

Key words: History, information technology, museum value, museology.

Let me begin by painting a picture. There is a large warehouse in an industrial area of a Finnish city. One part of the warehouse consists of a 400-square-metre space, filled with computers from floor to ceiling. There is everything from huge mainframes that weigh up to 1.5 tons, to small components such as graphics cards or CD-ROM drives. And everything is in jeopardy: the collection of the Finnish Data Processing Museum Association (FDPMA $)^{1}$ is under a threat of being broken up within a mere few weeks.

This was the situation in which the internationally important Finnish computer collection found itself in April 2007. This priceless collection of Finland's earliest computers was in serious trouble. But how did it come to this and what was the solution?
The story is long and interesting, but in the end it is a story of the survival of a museum collection. With the help of practical use of the concept of museality, the collection was saved and at the same time "rationalized" to form a collection of the most important computers used in Finland.

\section{A SHORT HISTORY OF COMPUTERS}

What is the importance of data processing or information technology in today's society? The use of computers has grown rapidly from a few mainframes in a whole country to almost every person having a personal computer of some sort. This history is "only" a century old, but it has already changed our everyday lives immensely. Our society is filled with the 


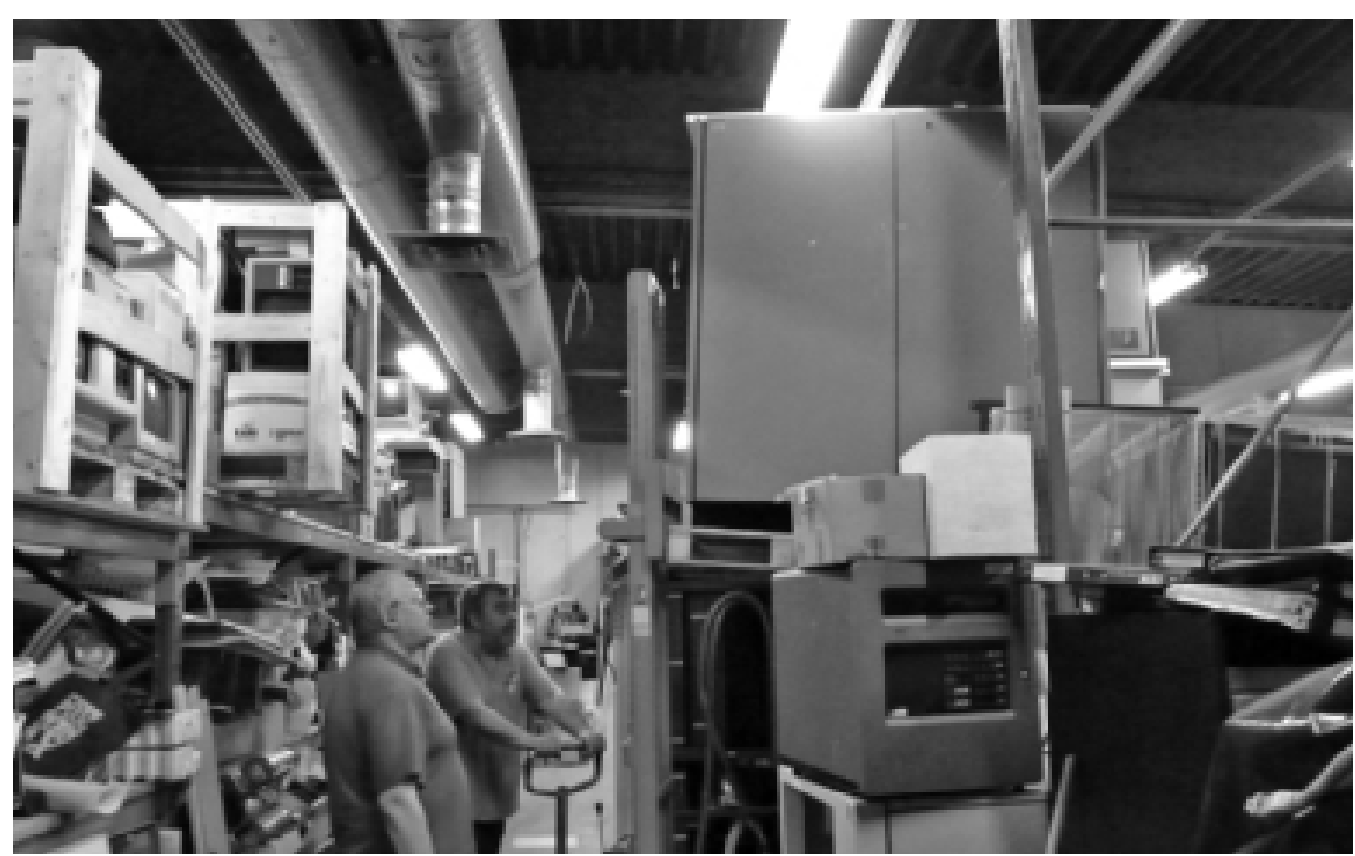

Fig. 1: A glimpse into the old storage facilities during the first day of the move. Kari Rantanen (left) and Timo Niinistö are taking a part of the EAI 640/680-computer down from a rack. This machine was used at the Finnish Research Centre for Science in the 1960s for simulations of Finland's first nuclear power plant. Photo: Jyväskylä University Museum, Photo archive: Emmi Tittonen.

machines that were initially designed to be part of scientific and commercial calculations. Nowadays, a computer is a part of every household, a vital part of our infrastructure and we are heavily dependent on them.

The history of computers begins from the period of the Industrial Revolution, when the Frenchman Joseph-Marie Jacquard invented and developed a loom that used punched cards to guide the weaving pattern. At the end of the 19th century, Herman Hollerith used this technology in the USA as a basis for his punch-card machines. The first Hollerith machines were used, for example, in the census in the USA. They were the first mechanical machines used for calculations. (Bashe - Johnson
- Palmer - Bugh 1986: 2-7; Suominen 2000: 39).

The development of these punch-card machines marked the beginning of computing. The first electronic computers began to be developed by universities and companies such as the International Business Machines (IBM) (Ceruzzi 2000: 13-46) during the 1950s. The first digital computer was the ENIAC computer that was built during the Second World War at the University of Pennsylvania, for use by the US military (Ceruzzi 2000: 15, 18, 2021.) The first generation of computers worked on the basis of vacuum tubes and drum memory (Ceruzzi 2000: 44-46).

The first actual computers were created for 
scientific computing, but they were soon used in commercial calculations as well. IBM in particular was an important developer and manufacturer that subsequently became the leading brand in commercial computing (Ceruzzi 2000: 47-78). After transistor technology became reliable and cheaper, the development began to grow immensely. By the 1960s, computers were used in commercial as well as scientific calculations, but they were also manufactured in great numbers (Ceruzzi 2000: 47-78). In 1965, Gordon E. Moore, the cofounder of Intel, made a statement in which he said that the number of transistors on a cheap computer chip would double every year. This statement, now known as Moore's Law, has proved to be correct as the size of transistors has diminished with the developing technology (The Intel website on Moore's Law; Tuomi 2002 chapter 3).

From the 1970s onwards, the development of the microprocessor marked a new era for computing (Ceruzzi 2000: 177-241). From minicomputers to microcomputers, the technology developed still further to the point in which we are now. During this era, punchcard technology was slowly superseded and with better memory technology, larger capacities were available. Different types of software were also developed, and in the 1980s the first word processing programs became available to users (Ceruzzi 2000: 177-241). Finally, development led to a point that has been described as the information society. The developing of networks, especially the Internet, has been a great influence on this.

In Finland, the history of computing is even shorter. The use of punch-card machines began in the 1920s, but they only really began to gain popularity after the Second World War. The first computer that came to Finland was an IBM 650 for use by the Postipankki bank, in 1958. At the same time, Finnish scholars were building a home-grown computer, based on a German model (Paju 2002; Suominen 2000: 47-56). Finnish universities also got their first computers by the beginning of the 1960s (Manninen 2003: 15-17; Suominen 2000: 47-56).

Like in many other countries, Finnish computing grew slowly. Computers were used in science and commerce, but also in corporations. In the 1970s, universities had got their first large computer in joint use, the Univac 1108. This also marked the beginning of Finnish data communications (Kauranne 1988: 4-8; Käpyaho 1996: 10-20). Nowadays, information technology is implemented in every part of our society. So in this retrospect, why is it hard to see why we should collect computers, whose history only extends over 100 years but which have changed our lives for good?

THE IMPORTANCE OF THE WORK OF THE FinNish DATA Processing Museum ASSOCIATION

In Finland, there is no specific museum with the obligation to collect computers. In the Finnish museum legislation, museums have a very general ordinance about what to collect. There is a certain degree of obligation to collect dead protected animals and stray prehistoric artefacts, whereas archives and libraries have more clearly defined instructions about what to collect.

Basically, in Finnish museums we have to decide for ourselves about what to collect and why. We do not have an organisation like the Swedish SAMDOK, which would collaborate on collecting contemporary phenomena, or 
172 the recent past, even though Finnish museums do, of course, collect objects associated with modern-day history. However, computers are not usually part of these collections. Only the Technology Museum of Finland has collected computers as one part of its collection (http://www.tekniikanmuseo.fi/). The Finnish Data Processing Museum Association (FDPMA) and the Technology Museum of Finland have an oral agreement on the focus of collecting: the association focuses on the larger computers whereas the Technology Museum of Finland mainly collects PCs.

In this situation, the work of the FDPMA, located in Jyväskylä in central Finland, has been ground-breaking. In the course of its 30year existence, it has focused on collecting the computers most important in Finnish history. Nowadays it has approximately 250 objects and related material in its collections. The aim of the museum association is to preserve and exhibit objects associated with information technology in Finland, and it also works on converting old formats into contemporary formats for private persons as well as various institutions and firms.

An IBM maintenance engineer, Mr. Ilari Taulio, started to collect computers in the 1970s. He began by asking his employer, customers and various institutions around Finland to donate their old computers. At first, these computers were placed in Mr. Taulio's home, but the collection grew rapidly so he had to start looking for other places to store them. In 1986, he rented a small storage space from the city of Jyväskylä. During that time, a museum committee was set up by Mr. Taulio to work on creating a national computer museum in Jyväskylä. The committee's first aim was to acquire proper storage space for the computer collection, second was to increase the collections and third was to exhibit the computers to the general public (JYU/KHO N3781:35; Ketky ry 1997: 54-57).

The museum committee worked on establishing the foundation of computer museum work in Finland. For example, in 1991 the committee rented a larger storage space for the collection. In 1995, the museum association was established to continue the work of the museum committee. The association's work has been based on the same principles as the committees: it still works on managing and increasing the collections, as well as exhibiting computers around Finland. The museum association consists of both people currently working in the computer industry and people who have retired from the field. The active members of the association have done everything as voluntary work in their spare time. The work of the FDPMA has largely been funded by contributions from a range of different sources (JYU/KHO N3781:35; Ketky ry 1997: 54-57).

The association has also maintained some machines in working condition to help people convert their files. For example, the association still has punch-card machines that actually work, and can be used, for example, to convert data from punch-cards to 3.5-inch floppy disks and CD-ROMs. One of the most important tasks they have done is the converting of files which contained the letters of one of Finland's most important writers, Elias Lönnrot (1802-1884). The association converted these letters from 8.5-inch floppy disks to contemporary formats and ever since, the letters have been available for researchers in today's format (JYU/KHO N3781:35).

The museum association also has two permanent exhibitions in Jyväskylä. The first was built in co-operation with Jyväskylä Universi- 
ty in 2000. It is located in the Agora building, which houses the Faculty of Information Technology. This exhibition has a few of the most important computers in the FDPMA collection, such as the Cray $1 \mathrm{~S}$. The second exhibition was established in co-operation with the Jyväskylä University of Applied Sciences in 2006 and is located in the IT-Dynamo building, which houses the Institute of Information Technology. The support of these institutions has been important to the museum association through the beginning of the current decade. With their help, access to the exhibitions is free of charge and available for everyone interested in seeing how computers have changed over time (http://www.tietokonemuseo.saunalahti.fi/index_eng.htm).

The University of Jyväskylä had good relations with the association from the beginning. The University had donated old computers to Mr. Taulio's collection and helped the association financially by giving them various contributions for their work. At the beginning of the current decade, the Jyväskylä University Museum and the Discipline of Museology began co-operation with the association. The Discipline of Museology arranged visits for students to see the collection and the museum association's exhibitions. The University $\mathrm{Mu}$ seum helped the association by consulting them on various issues.

2005 saw the beginning of planning a documentation project that aimed to increase the museum value of the computer collection. Even though it was important in international terms, the collection had low museum value. For example, it contained the MIR-2, probably the only Soviet computer of its kind outside the borders of the former Soviet Union. This had great historical value but there was no story to tell. The new documentation pro- ject was aimed at improving this situation along with the general awareness of the collection at national level. During that time, the outlines of the project were created. Everything seemed fine and the future bright, when the crisis struck.

\section{THE CRISIS IN THE FDPMA}

The main supporter of the association, the city of Jyväskylä, decided at the end of 2005 to withdraw its support. The city had contributed a sum of money every year that equalled the rent for the storage areas. This money was used solely to pay these rental expenses. (The decision of the cultural board of Jyväskylä 17.1.2006) Without this support, the association was in trouble: with no other major "financier", they had no money to pay the rent. In 2006, the association fought for its existence, but the city did not alter its decision (The decision of the Jyväskylä city council 10.4. 2006). The museum association even tried extreme measures: it was willing to donate the collection to the city. After due consideration, however, the city refused this offer (The decision of the Jyväskylä city council 8.5.2006).

With help from various sources, the association was nevertheless able to pay the rent and hang on. It was even able to start the project of increasing the museum value of the collections. The project started in November 2006, made possible by two contributions from the Ministry of Transport and Communications of Finland. But the situation got worse at the beginning of 2007: the landlord gave the association notice that the lease was to be terminated, stating that they had to be out in June. It looked like the collection would have to be demolished. The association had been promised finance for the rent, if this figure was 
174 reduced and the collections cut down in size. The association had already received funding for a move to new storage, but without funding for the rent, they were unable to undertake the move.

In April, the situation was terrible. In a few weeks, the collection would be destroyed, if no one would come to help. Fortunately, the association fought until the end. After a few futile attempts, the University of Jyväskylä came to its aid. With their help, a storage space 250 square metres in size was rented from an old area of the Finnish Defence Forces, the Kanavuori Caves. This facility used to be a storage area and factory for ammunition and supplies for the Finnish military. It is now owned by a private-sector entrepreneur that rents the space out to different tenants (http:// www.kanavuori.fi). The move to the new storage area was funded by contributions from the city of Jyväskylä, the rural municipality of Jyväskylä and the National Board of Antiquities. ${ }^{2}$ The collections could be saved, but at a price. With a space that was almost $50 \%$ smaller than the previous, the collections had to be reduced in size. What was probably the biggest task in the history of the museum association therefore began, in May 2007.

\section{THE PRACTICAL USE OF MUSEALITY}

The documentation project had already begun when the move became imminent. Since November 2006, I had been collecting the stories of 11 mainframes or computers that were in the FDPMA collections. The project was a part of a co-operation agreement between the museum association and University Museum, which ultimately aimed at saving the association's collections. With the help of museological principles, especially the theory of museum value (Mensch 1992; Valtonen 2006), the project aimed to collect information about the 11 chosen machines, aiming to increase the museum value of the collection as a whole. The results of the project would then be used to improve the cataloguing, as well as improving the exhibitions.

The project focused on 11 specific machines that were chosen from the museum association's list of "the most valuable". This list consists of 18 computers or machine groups ${ }^{3}$ that the association considers the most important in its collection in terms of the history of computing and information technology in Finland. This list was compiled during the time the documentation project was being planned, and has been the first step in valuing the collection based on the knowledge of the museum association's members. Most had been in use in Finnish universities or were the only ones of their kind in Finland or Western countries. This valuation of the collection was based on hard facts rather than any sentimental or aesthetic basis (Pearce 1995: 353-357).

The documentation project aimed to find out more about what had happened to the 11 selected machines ${ }^{4}$ during their service lives. This was a difficult task, because the association had little information about the stories behind these machines. I had to begin from the musealization of the objects, by gathering information about when the machines were donated and who the donors were. Through this knowledge, I was able to find the primary context for the machines - where they were used and when. I was also able to undertake research about the identity changes that the machines underwent, by combining literary and archive material with interviews of the people who had actually used them. In the end, I was able to find at least the donor facts for all 


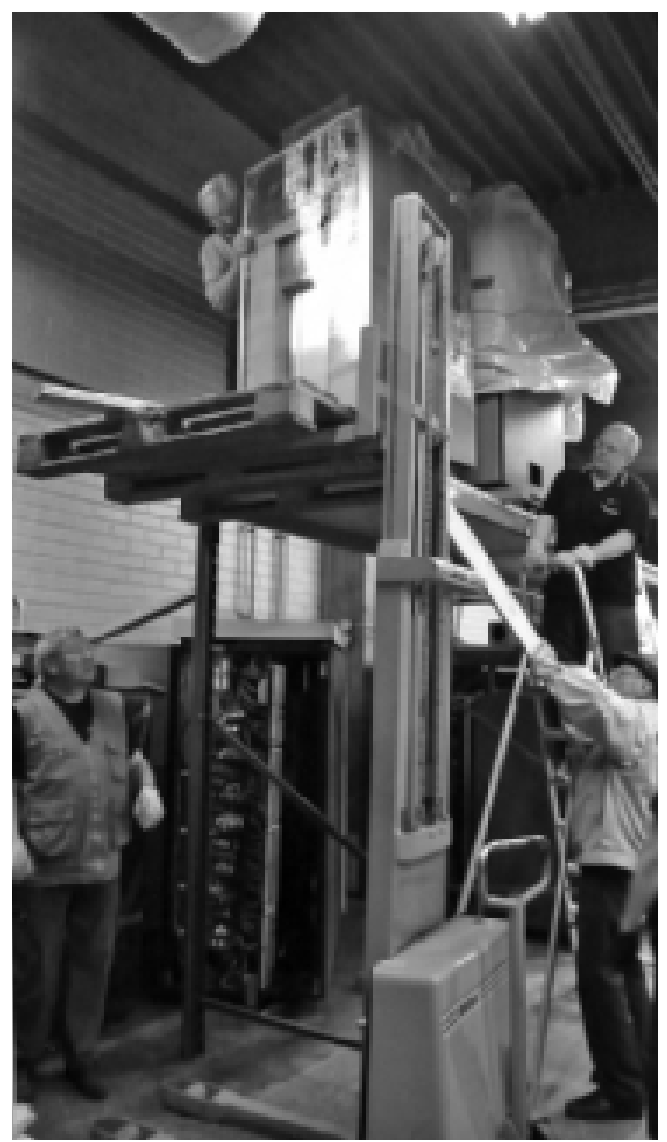

Fig. 2: An example of the difficulty of the move. This is also a presentation of the real skills required for moving large objects. Taking down the IBM tape unit took a few hours and several attempts before it reached the floor safely. The members of the association really proved their skill and: in the end it came down easily. In the picture are (from the left): Harri Grönberg, Ilari Taulio, Kari Rantanen and Martti Hakala. Photo: Jyväskylä University Museum, Photo archive: Emmi Tittonen.

of the machines and the life stories for some of them.

During the move, the most important museological guideline was the principle of $\mathrm{mu}$ - seum value. Some members of the association had studied museology, but they wanted help with the museological aspects of managing the move of a collection of this magnitude. The move started in May 2007 and extended into June. It was not an easy task, for two reasons. Firstly, the new storage facilities were almost $50 \%$ smaller than the previous storage space. The new space was also lower in height, so it was not so easy to utilize efficiently. The second reason was that the association had probably nearly a thousand objects in its collection. This number had to be reduced to fit into the new space.

It could be said that the museum association's collection was built up all over again during the move. The collection was large in terms of quantity, simply because there was no predetermined collection policy. Over the course of thirty years, the collection had grown uncontrollably, even though the association had put some effort into reducing and managing it. Like many museums around the world, the association in some cases had taken everything that was given to them. In addition, the accumulation of the machines in a limited space led to a point where the storage areas were too full to really be fully functional.

The process of selecting machines for the new collection was based on the original list of "the most valuable": the basis of the "new" collection is the 18 computers or machine groups that were on the original list. In a way, this list is based on the principle of the museum value. In this specific selection, the emphasis was on the cultural and communal context as well as the technological context. Although the cataloguing carried out by the association is inadequate, some of the machines from the list did have some contextual information even before the documentation 
176 project began. This involved gathering of contextual information, in particular, about the chosen machines. This made the original list a good basis for the selection. Also the fact, that those machines have been important in the history of Finnish information technology, was an important influence on the selection. The result was that all the machines on the list - in effect - defended their entitlement to be included in the new collection.

Ultimately, the members of the museum association carried out the selection based on the principle of museum value. Both before and during the move, the members of the association discussed the principles on which the selection would be based on. It was decided from the beginning that the concept of museum value would be the basis for selecting the machines that are on the list. However, it was difficult to define the museum value concerning this collection, when there was not much contextual information about the machines. Most of the knowledge resided solely in the minds of the association's members.

When the selection began, the basis was not only the list, but also the historical importance of the machines. All the selected computers not on the list had other importance. Some were the only ones of their kind ever used in Finland or otherwise important in considering the history of Finnish information technology. For example, a machine with the designation SKDL was built by the Finnish defence forces to be used in studies of computer technology. In this sense, the value of the new collection was also based on historical facts or importance at national level. The contextual information was the basis in case of machines that had this information available, but the selection was mostly based on historical importance. Machines from different points in the development trajectory were also chosen to represent the changes in technology. Aesthetic values were discussed, but were soon rejected because the association chose instead to emphasise the stories the machines could tell us.

Unfortunately, almost half of the computers in storage did not make the cut. All the duplicates and machines that were not really computers had to be left out. For example, there were two or three similar IBM punchcard machines but only one was selected. The association had collected duplicates, because they had hoped that one day they could put them on display where the museum visitors could touch and feel them. The lack of space also resulted in having to select only parts of large mainframes. Some of the mainframes from the 1970s could fill an entire room, making them too large for the new storage facilities. In such cases, the mainframes were left out, or only some parts of them were selected, chosen on the basis of the technology changes they represented.

Most of the machines that were left out had low museum value, in the sense that they had no "life story". There were even machines about which no one knew anything. By contrast, the "new" FDPMA collection had to have a justification for belonging to a museum, based on the concept of museum value and an emphasis on an object having a life story. The 11 computers or machine groups concerned, along with the seven other objects from the "most valuable list", now form the basis of the new collection. Every machine has contextual information, technological importance or significance in the history of Finnish computing.

Unfortunately, the smaller space made it impossible to take more than about $250 \mathrm{com}$ puters or mainframes. The time available for 
the move was also really short, so the selection could not be planned ahead. However, the list of "the most valuable" proved to be the best guideline for the selection. In the short time available, the stories associated with the machines could not be given great value, although the concept of museality did lie behind actions undertaken during the move. After selecting the machines on the list, they had discussed whether or not each machine on the list had museum value.

The number of machines in the new collection has been very hard to define, because the museum association had no collection policy, although the outlines of a policy were created in junction with this selection process. The number of machines in the old storage facilities was close to one thousand, with the machines on display being part of this estimate. But here lies the tricky part - how to define the number of objects? Should they be counted on the basis of components or systems? Is one component (e.g. the CPU of a large mainframe) an object, or does the whole mainframe count as an object? The difficulty lies in the lack of collection policy and the lack of specific terms by which the association measures the number of objects. There are no common or written principles in this matter, although they have been working on it.

The catalogues are not a good reference in this matter, because they are insufficient. During the move, we intended to write down which machines were selected and which were left out, but unfortunately there was no time or manpower to do this. In addition to this, not all the machines were in the catalogues before the move and some were featured twice due to the changes in the cataloguing principles. There were still 1500 objects listed, so it is not relevant for the count.
I have estimated the number of machines present in the storage facilities to be approximately 250 computers or mainframes, not including items actually on display - amounting to about 20 computers plus several components on display in them. The number 250 is ultimately my perspective on how to evaluate the number of the objects, based on the number of computers as a whole - which means that one mainframe is one object. For example, this means that the EAI Analogue computer, which has seven components, is one computer and thus one object.

The catalogues of the Aviation Museum of Central Finland are a good example of how to evaluate and define not only the basis of cataloguing, but also a collection policy and the number of objects included within the collection. The Aviation Museum has divided the objects into three major categories: museum objects, equipment and supply. Under these categories there are several smaller categories in which are, for example, airplanes listed as museum objects. Propellers and other parts of airplanes are also listed as museum objects (Valtonen 2006: 100-104). The FDPMA museum association should follow this example, perhaps by dividing the objects into three corresponding categories under which a computer would be one museum object, punch-cards containing a program another and maintenance supplies a third. The developing of such catalogues as well as the setting up of a collection policy are part of the association's future plans.

Anyway, the move gave the association a fresh new start. A crisis can mean the death of something but it can also provide an opportunity for renewal. In this specific case, the FDPMA survived a crisis during which they had to evaluate and renew its work in order to 


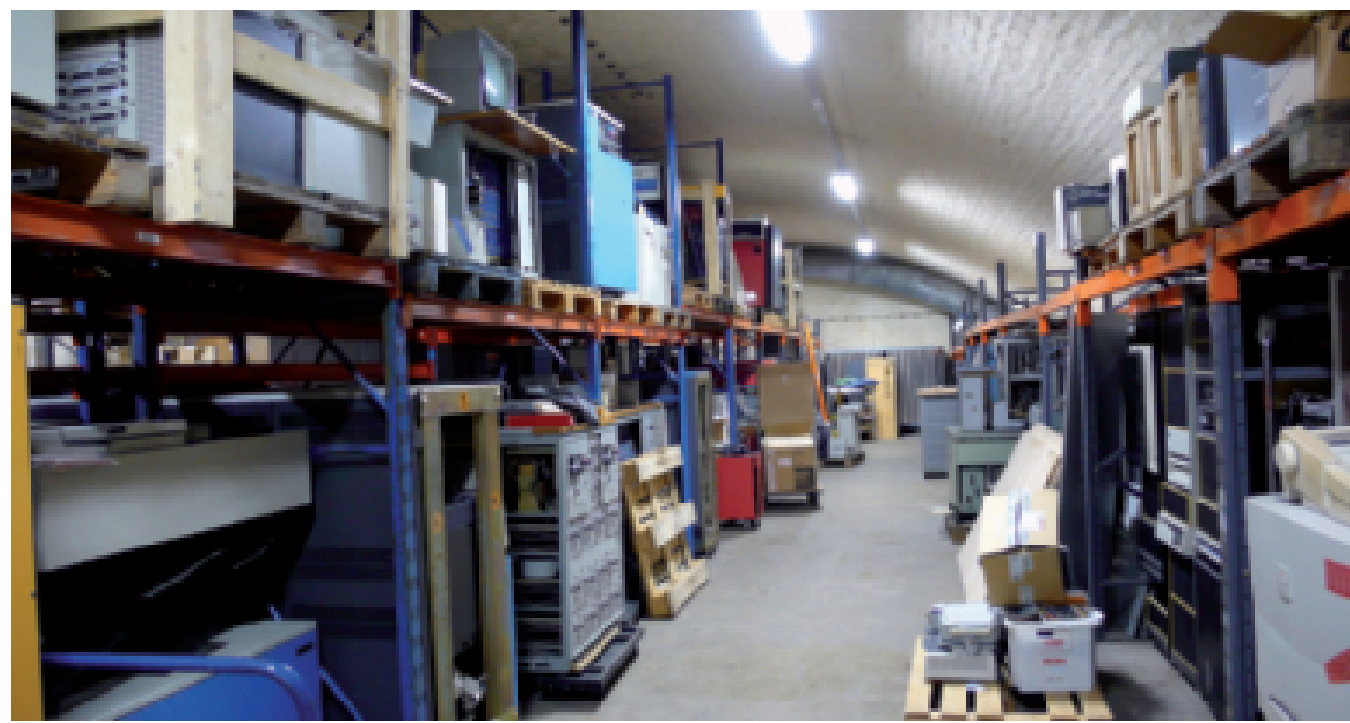

Fig. 3: The new storage facilities in Kanavuori. This space was difficult, because of the roof. The machines could not be placed in two storeys at the side: this was only possible in the middle row. The storage is organised in four rows, as an exhibition, so that it is easy to see the machines. Photo: Jyväskylä University Museum, Photo archive: Emmi Tittonen.

survive. The new storage areas are smaller but the rent is also lower. The association has received funding from several sources to maintain its work and possible future projects, but also to pay the rent on the new storage areas. The collections are now of manageable size, and future increases are possible with the help of the collection policy outlines created during the selection. The new storage facilities are also presentable to the public, and will be organised so that the machines can be viewed properly.

The future for the FDPMA currently seems bright. The association is looking forward to developing its work and they have started new projects in order to bring knowledge about their collection to the public. For example, a virtual museum project has been launched in co-operation with the Jyväskylä University of
Applied Sciences. New websites are also under construction. Now the association can get back to its work of preserving, exhibiting and studying the history of Finnish information technology.

\section{THE CRAY $1 \mathrm{~S}$ - FINLAND'S "FIRST" SUPERCOMPUTER}

As an epilogue, I want to present to you a success story of the documentation project. I will tell the story of the Cray $1 \mathrm{~S}$ computer that was one of the machines studied. It was also one of the machines whose museum value was increased. In the computer exhibition in the Agora building stands a big pink computer that is a central processing unit (CPU) of the Cray $1 S$ supercomputer. The Cray $1 \mathrm{~S}$ is considered to be the world's first supercomputer $-\mathrm{a}$ 
large computer system especially for extensive computing (The CRAY 1S - advertisement from the 1970s). But all the parts, that would make it a working computer, have been removed from the Cray $1 \mathrm{~S}$ on display.

To tell its story, the story of another machine has to be told. At the end of the 1970s, the Ministry of Education in Finland set up a committee to plan the purchase of a new mainframe for joint use in Finnish universities as the successor for the Univac 1108 mainframe. At the end of the 1980s, Finland finally got its first supercomputer, the Cray X-MP $\mathrm{EA} / 416$. It was taken to service in January 1989 on the premises of CSC - the Finnish IT centre for science (Kauranne 1988: 4-8; Käpy- aho 1996: 10-20; JYU/KHO N3781: 50; Serimaa 1988).

When the Cray X-MP arrived in Finland, there was great interest amongst the public wanting to see the machine that had taken years to obtain. It was strictly forbidden for any unauthorized person to enter the machine room of Cray X-MP. Because of the great interest, CSC personnel asked representatives of the Cray Corporation if they could get a computer to put on display. An out-of-use Cray $1 \mathrm{~S}$ $\mathrm{CPU}$ was brought to Finland at the beginning of the 1990s (JYU/KHO Duo N3781:35; JYU/KHO Duo N3781:50). This CPU was on display in the entrance hall of CSC's premises in Otaniemi as a representative of the

Fig. 4: The CPU of the Cray IS Supercomputer, representing Finland's first supercomputer. The pink machine still invites people to sit on the couch on its bottom, just as it did originally. This couch actually hid the cooling components of the CPU. Photo: Jyväskylä University Museum, Photo archive: Emmi Tittonen.

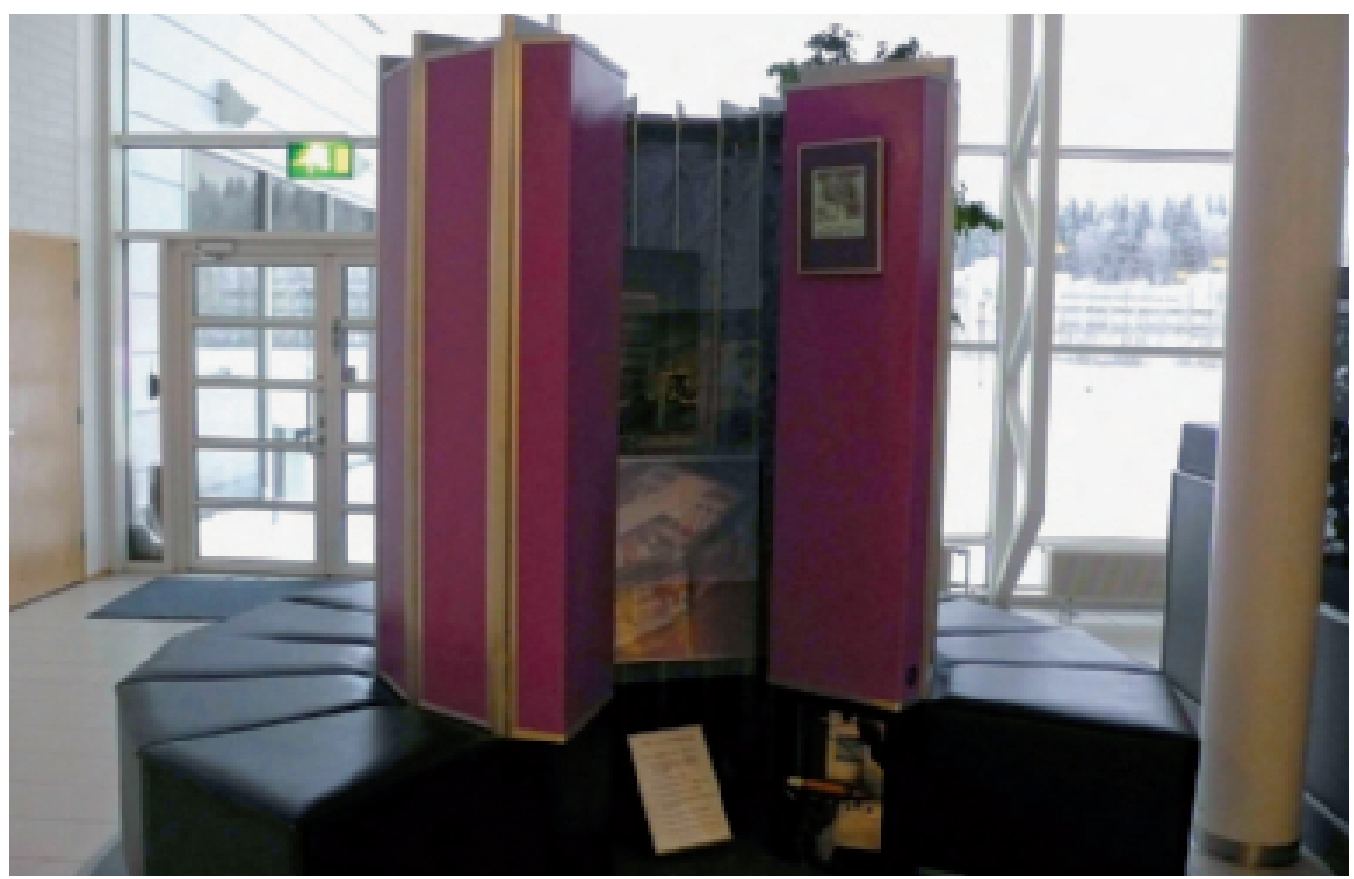


180 Cray X-MP. Everyone who visited the building could see what "Finland's first supercomputer" looked like, and even sit on the benches of the Cray 1S (JYU/KHO Duo N3781:48).

In 1991, one of those active in the museum association, Mr. Harri Grönberg, had listened to a radio show in which CSC talked about the Cray $1 \mathrm{~S}$ and its probable demolition before the arrival of a new supercomputer. Mr. Grönberg decided to contact CSC immediately and was able to arrange the donation of the Cray $1 S$. When it arrived to Jyväskylä, the museum association's members studied the CPU's technology. Later that year it was put on display in what was to become the exhibition in Agora (JYU/KHO Duo N3781:35). For the past six years, the Cray $1 \mathrm{~S}$ has again been on display to represent the Cray X-MP supercomputer, just as before.

In the project, the museum value of the Cray $1 S$ was increased by gathering sufficient contextual information. According to the interviews, the machine has two different stories. The first is that the computer had been used by Shell Corporation in the Netherlands for calculations associated with oil exploration. Due to Finland's geographical proximity to the Soviet Union and to ensure the technology could not be copied by Soviet interests, it was stripped of all essential parts before delivery to Finland (JYU/KHO Duo N3781:35). The other story in circulation about the Cray $1 S$ recounts that it came from a meteorological institute in England and had been used for meteorological calculations in a manner similar to the way the Cray X-MP would be used in Finland (JYU/KHO Duo N3781:50; Kauranne 1988: 4-8).

However, there is also a third story that may reveal why the CPU was stripped out. A similar Cray X-MP that had been in use in Nor- way was also stripped of all vital parts once no longer in service and before it was donated to the Technology Museum of Norway. At that time, the technology to be found inside the Cray computers was regarded as highly classified. Every machine was delivered to the customer under stringent security measures and even when the machines went out of service, Cray representatives arrived to take away key components because the technology behind the Cray computers had to be protected against industrial espionage. It is also possible that the parts were considered important because they could be reused and were made of valuable metals, including gold. During the Iron Curtain era, there were also strict trade agreements that prohibited the sale of Western-made machines to Eastern-bloc countries. However, the Soviet espionage aspect of this story is improbable in the case of the Norwegian Cray X-MP because it was stripped after the fall of the Soviet Union (Ola Nordal 12. 10.2007).

These stories, once aligned with the written material available about the Cray $1 S$ computers, increased the museum value of the machine on display. This more comprehensive story is now available in written form, not only in the memories of the association's members or its users. Its place in a museum is also justified. As a document of the beginning of the supercomputer era in Finland, the Cray $1 S$ has a story to tell. It is also the focus of the computer exhibition in Agora, just as it was the focus of interest when it served to represent the Cray X-MP. Even today, it represents both itself (Cray 1S) and the first supercomputer in Finland (Cray X-MP) as the beginning of the supercomputer era in Finland as well as internationally. 
NOTES

1. Suomen tietojenkäsittelymuseoyhdistys ry. (FDPMA) http://www.tietokonemuseo.saunalahti.fi

2. The decisions to contribute to the move: the cultural board of the city of Jyväskylä 10.4.2007 http://www3.jkl.fi/paatos/kulk/2007/10041700. 0/frmtxt43.htm; the Rural Municipality of Jyväskylä, decision of council \$165 2.4.2007 http://www.jklmlk.fi/; the National Board of Antiquities http://www.nba.fi/fi/harkinnanvaraiset_avustukset

3. The list of "the most valuable" consists of these 18 computers or machine groups: Wegematic 1000, Elliot 803 A, IBM 1620, EAI Analogue Computer model 640/680, IBM punched-card machines, IBM Ramac 305, MIR-2 (Soviet computer), Cray 1S, Zuse Z23, Digital Inc.'s PDP computers, Spear Inc.'s $\mu$-Linc a.k.a. Mikro-Linc, Almex Optical Reader, IBM mainframes (System 3 and 7, 3032), Data General Nova, SM-4 (CM4, Soviet PDP-11 clone), PCs and minicomputers from several manufacturers (e.g. IBM, Nokia, HP). The list is in the archives of the museum association.

4. The documented machines were these $11 \mathrm{com}-$ puters or machine groups: Wegematic 1000, Elliot 803 A, IBM 1620, EAI Analogue Computer model 640/680, IBM punched-card machines: from card punch to tabulator and reproducing machines etc., IBM Ramac 305, MIR-2 (Soviet computer), Cray 1S, Zuse Z23, Digital Inc.'s PDP computers: especially PDP-11, Spear Inc.'s $\mu$-Linc a.k.a. Mikro-Linc. The list is in the archives of the museum association.

\section{REFERENCES}

\section{Archive material}

The Finnish Data Processing Museum Association's archive material - Letters, written agreements of donations, applications of funding to various institutes, etc. Archive material (unorganized) is currently located in the association's storage facility in Jyväskylä.

The collections of the Jyväskylä University Museum, section of Cultural History JYU/KHO Duo 3781: 1-104 - the material collected in the documentation project includes interviews, archive material and journals.

\section{Internet references}

The CRAY 1S - advertisement from the 1970s: http://archive.computerhistory.org/resources/text /Cray/Cray.CRAY1S.1979.102646188.pdf 16.1.2008

Finlex® Up-to-date legislation on the Internet. The Law of Museums (in Finnish): http://www.finlex.fi/fi/laki/ajantasa/1992/19920729?search $\% 5$ Btype $\% 5 \mathrm{D}=$ pika\&search $\% 5$ Bpika $\% 5 \mathrm{D}=$ museolaki 16.1.2008

The Finnish Data Processing Museum Association (in English): http://www.tietokonemuseo.saunalahti.fi/index_eng.htm 16.1.2008

The decisions of the cultural board of Jyväskylä (in Finnish): The decision on 17.1.2006: http://www3.jkl.fi/paatos/kulk/2006/17011700. 0/frmtxt8.htm 16.1.2008

The decision on 14.3.2006: http://www3.jkl.fi/paatos/kulk/2006/14031700.0/frmtxt32.htm 16.1.2008

The decision on 10.4.2007 http://www3.jkl.fi/paatos/kulk/2007/10041700.0/frmtxt43.htm

\subsubsection{8}

The decisions of the city council of Jyväskylä (available on the Internet in Finnish):

The decision on 10.4.2006: http://www3.jkl.fi/paatos/kh/2006/10041400.0/ frmtxt153.htm 16.1.2008

The decision on 8.5.2006: http://www3.jkl.fi/paatos/kh/2006/08051400.0/ frmtxt179.htm 16.1.2008 
The National Board of Antiquities (in Finnish): http://www.nba.fi/fi/harkinnanvaraiset_avustukset 24.1.2008

The rural municipality of Jyväskylä (in Finnish): http://www.jklmlk.fi 24.1.2008

The Technology Museum of Finland (in Finnish): http://www.tekniikanmuseo.fi/ 16.1.2008

The Intel website on Moore's Law: http://www.intel.com/technology/mooreslaw/index.htm 16.1.2008

Interviews:

JYU/KHO Duo 3781: 35, 7.12.2007

JYU/KHO Duo 3781: 48, 26.3.2007

JYU/KHO Duo 3781: 50, 26.3.2007

e-mail correspondence with Ola Nordal M.A, 12.10.2007. Information published with Mr. Nordal's consent.

\section{Publications}

Bashe, Charles J. - Johnson, Lyle R. - Palmer, John H. - Pugh, Emerson W. IBM's Early Computers. Massachusetts Institute of Technology: London 1986.

Ceruzzi, Paul E. A History of Modern Computing. Massachusetts Institute of Technology: London 2000.

Heinonen, Jouko - Lahti, Markku: Museologian perusteet. Kolmas uudistettu laitos. Gummerrus: Jyväskylä 2001.

Kauranne, Tuomo: Maamme matkalla maineeseen eli kuinka tullaan supertietokoneen omistajaksi. Korkeakoulujen atk-uutiset 3-4/88: 4-8.

Ketky ry:n hallitus (toim.): Ketky ry 25 vuotta, Juhlajulkaisu. Ketky ry: Saarijärvi 1997.

Käpyaho, Juhani: Tieteen tietokoneet ja tietoyhteydet. CSC - Tieteellinen laskenta 25 vuotta. CSC: Espoo 1996.

Manninen, Ari T: Näin tehtiin Suomesta tietoyhteiskunta. Gummerrus: Jyväskylä 2003.

Mensch, Peter van: Towards the theory of museology. PhD. -thesis published on the Internet, available at http://web.archive.org/web/20000422030557/ www.xs4all.nl/ $\sim$ rwa/contents.htm 16.1.2008

Paju, Petri: Ensimmäinen suomalainen tietokone ESKO ja 1950-luvun suunnitelma kansallisesta laskentakeskuksesta. Lisensiaatintutkimus, Turun yliopisto kulttuurihistoria. Painamaton opinnäyte. Turku 2002.

Pearce, Susan M.: On collecting. An investigation into collecting in the European tradition. Routledge: London 1995.

Serimaa, Olli: Supertietokone. Korkeakoulujen atkuntiset 3-4/88: 15-23.

Suominen, Jaakko. Sähköaivo sinuiksi, tietokone tutuksi. Tietotekniikan kulttuurihistoriaa. Nykykulttuurin tutkimuskeskuksen julkaisuja 67. Gummerrus: Jyväskylä 2000.

Tuomi, Ilkka. The Lives and Death of Moore's Law. First Monday, volume 7, number 11 (November 2002). URL: http://firstmonday.org/issues/issue7_11/tuomi/index.html 16.1.2008.

Valtonen, Hannu: Tavallisesta kuriositeetiksi. Kahden Keski-Suomen Ilmailumuseon Messerschmitt Bf 109-lentokoneen museoarvo. Jyväskylä studies in Humanities 49. Jyväskylän yliopisto: Jyväskylä 2006.

*Emmi Tittonen M.A. is a post-graduate student at Jyväskylä University and worked as a project researcher in the documentation project of the collections of the Finnish Data Processing Museum Association. The project was conducted in the Jyväskylä University Museum, Section of Cultural History between October 2006 and December 2007.

Address: Jyväskylä University Museum Section of Cultural History P.O.Box 35 40014 University of Jyväskylä, Finland E-mail: emtitton@jyu.fi 